The Journal of Society and Media, April 2021, Vol. 5(1) 19-41

https://journal.unesa.ac.id/index.php/jsm/index

E-ISSN 2580-1341 and P-ISSN 2721-0383

Accredited KEMENRISTEK/ BRIN No.148/M/KPT/2020

DOI: 10.26740/jsm.v5n1.p19-41

\title{
Strangers at Home: Identity Negotiation Practices among Ethnic Chinese in Madura, Indonesia
}

\author{
Medhy Aginta Hidayat ${ }^{1^{*}}$, Mohtazul Farid ${ }^{2}$ \\ ${ }^{1,2}$ Faculty of Social and Cultural Sciences, Universitas Trunojoyo, Madura, Indonesia \\ Email: medhy.hidayat@trunojoyo.ac.id \\ Email: mohtazul.farid@trunojoyo.ac.id
}

\begin{abstract}
This study examines the identity negotiation practices among ethnic Chinese in inter-ethnic relations in Madura, Indonesia. Even though ethnic Chinesse have been living in Madura for quite a long time, they are still often considered as "strangers" by most of native Madurese. This study used qualitative data from literature review, field observations, and in-depth interviews with fifty informants of the ethnic Chinese who were born and lived in Madura. This study found that the practice of identity negotiation carried out by the ethnic Chinese in Madura includes several ways: using local language in daily conversation, changing their Chinese names into native Madurese names, practicing the Madurese indigenous cultural traditions in daily life, embracing Islam - the majority religion of the native Madurese - as their new religion, and marrying native Madurese men or women. The findings of this study corroborated prior studies that in unequal inter-ethnic relations, the ethnic minority often have to sacrifice themselves to be accepted by the ethnic majority. Moreover, ethnic minorities often have to negotiate identities, by hiding their master identity and highlighting other minor identities in order to be accepted and coexist with the ethnic majority.
\end{abstract}

Keywords: identity negotiation, ethnic Chinese, inter-ethnic relations, Madurese

Paper type: Research paper

*Corresponding author: medhy.hidayat@trunojoyo.ac.id

Submited: 2020-11-28; Accepted: 2021-04-26; Published: 2021-04-28

Cite this document: Hidayat, Medhy Aginta, and Mohtazul Farid. (2021). Strangers at Home: Identity Negotiation Practices among Ethnic Chinese in Madura, Indonesia. The Journal of Society and Media, 5(1), 19-41. DOI: 10.26740/jsm.v5n1.p19-41 


\section{INTRODUCTION}

Indonesia is a country with thousands of ethnic groups. There are approximately 1300 ethnic groups in Indonesia (Arifin, Hasbullah, and Pramono 2016). Diversity seems to be the primary source that became raison d'etre of Indonesia. However, ethnic differences often become sources of horizontal conflict between different ethnic groups in Indonesia (Davidson 2003). Several ethnicidentity-based conflicts in Indonesia include the Ambon conflict, the Poso conflict, and the Sampit conflict (Davidson 2003; Hoon 2006; Setiono 2008). Although these conflicts are actually caused by the imbalance of economic, political, and cultural power relations, it must be recognized that the ethnic identity backgrounds seems to playing an important role for the many incidents of the inter-ethnic conflicts in Indonesia.

One of the ethnic minority groups that often become the victims of interethnic conflict in Indonesia is ethnic Chinese or Tionghoa (Heidhues 1996). Ethnic Chinese in Indonesia for long has been stereotyped as immigrant or "orang Asing" (non-native) and "Aseng" or minority groups (non-Muslim), and these stereotypes had have developed an anti-Chinese sentiment in Indonesia (Dawis 2010; Freedman 2003; Hoon 2006; Setijadi 2017). Historical records showed that the ethnic Chinese in Indonesia have become victims of inter-ethnic conflicts since the Indonesia's independence in 1945 (Freedman 2003; Turner and Allen 2007). In the postindependence era, a number of cases of violence against ethnic Chinese still reoccur in Indonesia (Davidson 2003; Heryanto 1998; Sai and Hoon 2012; Tan 1987, 2008). Mass violence during the Indonesia's 1998 Reformasi riots also re-involved the ethnic Chinese as the victims of violence conflicts in various places around Indonesia (Dawis 2010; Freedman 2003; Turner and Allen 2007).

However, cases of conflict involving ethnic Chinese actually do not occur in all regions in Indonesia. In a few regions, the Chinese-Indonesians are relatively acceptable and able to live in harmony with their fellow native Indonesians. A number of studies have shown that the ethnic Chinese in Madura have conducted voluntary assimilation and acculturation successfully (Dawis 2010; Erawati 2012; Hoon 2006). In many places in Madura, for example, it can be easily found Chinese villages (Kampong Pecenan) that live side by side in peace and harmony with pesantren or traditional Islamic boarding schools that are scattered around Madura Island. The identity issues seem not to arise and trigger ethnic-based-conflicts 
between the native Madurese majority and the Chinese-Indonesian minority in Madura (Heidhues 1996).

Contemporary studies of identity believe that identity is always created, constructed, and managed in everyday life (Brekhus 2015; Cohen and Kassan 2018). According to (Goffman 1959), argues that individuals tend to display their identity in such a way as to impress others around them. 'Impression management' is a concept introduced by Goffman to explain the ways individuals display their identities in different contexts (1959). In this sense, Goffman's impression management can be understood as the initial references to the practice of identity negotiation where the social actor tends to take actions in his interests in daily social interactions (Goffman 1959).

The concept of identity negotiation is based on the assumption that people enter their social interactions with specific goals in mind and try to establish a mutual identity that enables them to attain these goals. A process of negotiation ensues and, if successful, a working consensus emerges that defines the identity that each person is to assume during the interaction. From then on, the interaction proceeds until the participants have achieved their goals or one partner decides not to honor the identity that he or she has negotiated (Swann 2005).

The concept of identity negotiation can be traced back to the symbolic interactionism of George Herbert Mead (Scott 2016; Swann 1987, 2005; Swann, Johnson, and Bosson 2009) who emphasizes the role of social actors in social interaction. In the perspective of symbolic interactionism, the social actor conveys messages in the form of actions or personal appearances that will be interpreted by the recipient of the message in the process of social interaction. Mead's idea was further developed by Goffman (1959) who explained the process of symbolic interactionism as a dramaturgy. In the idea of dramaturgy, Goffman envisions the social world as a performance stage, where the front stage is the arena where social actors or individuals must carry out specific roles facing an audience or other people; while back stage is the arena behind the stage or behind other people where the social actor can more freely be himself (Goffman 1959). Goffman states that the task of each individual in social interaction is to build agreement on the roles that each person has as in a dramaturgy. In this light, the ultimate goal of the most common identity negotiation practice is thus to maintain harmonious relationships 
in social interactions within diverse groups or environments (Swann and Bosson 2008; Swann et al. 2009).

Identity negotiation practice may include several components, one of which is the practice of self-presentation to display certain identities in front of others (Swann and Bosson 2008; Ting-Toomey 2015). However, identity negotiation practice is not identical with self-presentation itself. An individual who chooses to move from one identity domain to another does not necessarily describe the concept of identity negotiation as a whole. The practice of self-presentation is usually carried out by individuals as a tactic to get symbolic rewards or meet social demands in certain social interactions. In this regards, self-presentation tend to emphasize the 'pleasing others' aspect. On the other hand, the practice of identity negotiation refers more to the efforts of individuals to find a balance between an individual's desire to appear in front of others and an individual's desire to fulfill the ideal of their own identity. In this situation, an important process of identity negotiation practice is marked by the absence of external coercion and the emergence of internal awareness to adapt harmoniously to a new and different environment (Swann and Bosson 2008; Ting-Toomey 2015).

In the study of contemporary sociology of identity, there is also a view that identity has never had a single dimension. The concept of identity always implies the character of intersectionality; it is formed from various cross-sectional slices of many identity attributes such as race, ethnicity, social class, gender, religion, citizenship, geographical position, social status, occupation, tastes, hobbies, life experiences, friendship networks, or family relationships (Brekhus 1996; Brekhus et al. 2010; Hidayat 2016). Moreover, identity is not only a social construction but also a biographically grounded, emotionally charged way of experiencing everyday life situations. Individual identity is thus a dynamic meeting between many different elements.

Furthermore, according to (Brekhus 2008) states that individuals always negotiate identities when presenting themselves in everyday life. Brekhus proposed the concept of 'marked identity', the idea that there are a number of identities attributes that are intentionally highlighted or openly displayed by individuals in social interaction, and 'unmarked identity', the idea that there are also intentional identity attributes hidden or covered in the process of social interaction (Brekhus 2008). Brekhus introduced a typology of identity presentation based on these 
marked and unmarked identities, which consisted of 'identity lifestylers', 'identity commuters', and 'identity integrators' (Brekhus 2008). Referring to Brekhus, an 'identity lifestyler' is an individual who tends to choose a particular form of marked identity and then regulates all aspects of their lives based on their chosen master status identity. In this sense, a lifestyler does not feel the need to negotiate identity because he/she has only one main marked identity (Brekhus 2015). Meanwhile, an 'identity commuter' is an individual who tends to move and negotiating identities, from one marked identity space to another marked identity (Brekhus 2015). An identity commuter, for example, might be an office worker who moves from the appearance of a professional identity (first marked identity) during the day to the appearance of another identity as a cafe singer (second marked identity) at night. Finally, an 'identity integrator' is an individual who tends to see himself/herself as an interwoven of different attributes and dimensions of identity in the same situation and time. An identity integrator has multiple identities marked together; and without one dominant identity or master status (Brekhus 2015).

In the context of inter-ethnic relations, the practice of identity negotiation does not only involve the 'marked identity' of ethnic background. In everyday life interactions, it is a common for an individual to manage and maximize the identity capital he/she has, both in terms of marked and unmarked identity, to fulfill his/her interests. It is through this process of negotiating the marked and unmarked identity attributes that the process of adjusting, bargaining, giving, and receiving identity voluntarily between ethnic groups becomes an important effort to build social interaction that is mutually respectful, tolerant, and harmonious. By taking into account these understandings, this study explores the multiple ways in which ethnic Chinese minority in Madura are negotiating their identities in everyday life situations. So, the next novelty, this study would like to see how the identity negotiating practices of ethnic Chinese in everyday life may encourage and maintain the social harmony in a predominantly Muslim population of Madura Island. 


\section{METHOD}

This study used a qualitative method with a phenomenological approach. Alfred Schütz's Phenomenology is a research approach carried out by revealing the hidden meanings behind the subjective experiences of individuals (Creswell 2013). The process of expressing the meanings of subjective experience into an objective or universal meaning was done by apprehending to the story of the subject's personal experience and then analyzing the narratives delivered based on specific themes. One important aspect of phenomenology is the process of 'bracketing out', in which the researcher tries as far as possible to abandon personal experiences and guesses during the stages of research (Creswell 2013). In the context of this study, through a phenomenological analysis process, it was hoped that an understanding of the practices of negotiating the identity of ethnic Chinese in inter-ethnic relations in Madura would be obtained.

This study began with initial field observations to gain an early understanding of the location and the subject of the study. Observations were made mainly in the central areas of the ethnic Chinese community or in Kampong Pecenan in Bangkalan Regency and Sumenep Regency, Madura. Kampong Pecenan actually exists in every regency in Madura (Bangkalan, Sampang, Pamekasan, Sumenep). However, this research was consciously focused on the two most western and eastern regencies in Madura, namely Bangkalan and Sumenep. This was deliberately chosen to see the differences in social and cultural characters between the people of West Madura and East Madura, which could have influenced the identity construction process of ethnic Chinese in Madura. The process of selecting informants for this study was based on the need to answer the research questions. The informants were individuals who came from ethnic Chinese who were born and lived in the research location, understood the ethnic Chinese culture and interacted directly with the ethnic Madurese. The selection of informants in this study was made by considering the principle of diversity of backgrounds and identity attributes possessed by the informants. In total, there were fifty informants who were interviewed for this study.

The data collecting process for this study was conducted from April to September 2019, in two ways, from primary data sources through field observations and in-depth interviews, as well as from secondary data sources through literature 
reference, news media, scientific documentation, pictures, and photographs. Indepth interviews were conducted semi-structured with the help of interview guides and digitally recorded. Each interview lasts for approximately one hour. The interview data then be transcribed by the research assistant and translated from Madurese into Indonesian for analysis.

Data analysis in this study was carried out through three stages (Creswell 2013). First, reading data and making code (coding), and clustering or labeling the themes that emerged most in the in-depth interview process. In this first stage, the researchers carried out the process of reading the interview transcripts repeatedly to find the most frequently emerging themes regarding the negotiation process of ethnic Chinese identities in Madura. These themes were then used as the basis for coding. These themes include the language used by ethnic Chinese in Madura, the names used by ethnic Chinese in Madura, cultural attributes and customs practiced by ethnic Chinese in Madura, the religion adhered to by ethnic Chinese in Madura, as well as spouses or families of ethnic Chinese in Madura. Second, sorting data according to the most relevant themes appeared to answer the research problem formulation. Not all themes that appeared in in-depth interviews were thus relevant to answering the research questions. In this second stage, the researchers performed data reduction by removing a number of data that did not answer the research questions and only made use of the data that specifically answered the research questions. Third, interpreting and synthesizing the results of in-depth interviews that were subjective and abstracting them in order to find objective or universal meaning from the findings of phenomena in the field. In this third stage, the researchers compiled a scheme of the forms of identity negotiation carried out by ethnic minorities (namely ethnic Chinese) who live in the majority ethnic community (namely ethnic Madura). Finally, the researchers concluded and compiled a report on research findings regarding the practices of identity negotiation of ethnic Chinese in inter-ethnic relations in Madura, Indonesia. Presentation of the results was made by describing the main findings and having theoretical discussions relating to the findings generated in this study. 


\section{RESULTS AND DISCUSSION}

Using Madurese in Daily Conversations. Most informants of the ethnic Chinese in this study stated that their ancestors did not originate from Madura. Some informants shared the history of their ancestors, many of whom came from Java Island, especially from coastal cities such as Jakarta, Semarang, Surabaya, Cirebon, Pati, and Tuban. Almost all informants in this study were not the first generation of the ethnic Chinese who migrated to Madura. Most of the informants in this study were the third generation of ethnic Chinese descent in Madura, and almost all of them were born in Madura. The influence of the native Madurese culture, thus, has been felt by the informants in this study since they were born. Of the various attributes of Madurese culture that have been inherent since early childhood, one of them is their ability in speaking Madurese language in the daily interactions.

"Since I was a child, my parents have taught me Madurese. I didn't even know Mandarin. I also went to public school, not to a private school like in the SDK (Sekolah Dasar Kristen or Christian schools). When in junior high school, I only have two or three Chinese friends. When I used Madurese, like when I phoned my friends, my Madurese accent was "cek kataranah" (very strong). When I travel outside Madura, people thought that I'm not Madurese, until I speak Indonesian with a strong Madurese accent. My accent cannot be deceived because I was born and been living in Bangkalan, Madura" (Grace, female, 43 years old).

"When I communicate with my family in Java, I use Javanese. Yet when I communicate with my family in Madura, I use Madurese, or sometimes Indonesian. It's the same when I communicate with people around me, if not Madurese, I use Indonesian. But never Mandarin. I don't really know Mandarin because my family doesn't really use it as well" (Arista, female, 23 years old).

As revealed in the interview excerpts from the two informants above, namely Grace and Arista - both ethnic Chinese women who speak very fluently in Madurarese, most of the informants in this study also admitted that they were fluent in speaking Madurese. Specifically, the informants in this study who were older adults had a relatively better ability in speaking Madurese than the younger informants. In addition to being able to speak casual (low-level) Madurese, which is commonly used in daily conversations, some older informants are also able to speak polite (high-level) Madurese, which is quite difficult and has now begun to be rarely used among native Madurese. On the other hand, most of the younger 
informants in this study admitted that they were only able to speak casual (lowlevel) Madurese, which was widely used among youths in daily conversation in Madura.

The mastery and use of Madurese language by ethnic Chinese in daily life is one of the main strategies in the practices of identity negotiation of ethnic Chinese in Madura. Most informants in this study admitted that the ability to speak Madurese was important in interacting with native Madurese (Aguilar 2001). By being able to speak Madurese, they find it easier to be considered as native Madurese. Referring to (Goffman 1959), daily social interaction is a 'front stage' where individuals tend to display good impressions, so they are readily accepted in interactions with others. Everyday life is an arena where the self performs in some different ways depending on time, place, and audience (Goffman 1959). In other words, impression management, in this light of language skills, is crucial in the practices of identity negotiation. By being able to speak Madurese well, the ethnic Chinese tend to be more readily accepted and considered as part of the native Madurese in their daily interactions. Those who were initially seen as 'outsiders' would immediately be accepted as 'insiders' when they are able to communicate in Madurese properly. Most of the informants in this study also stated that without the ability to speak Madurese well, the process of adaptation and their acceptance in inter-ethnic relations in Madura might not have proceeded smoothly. In other words, language adaptation is one of the main and first strategies to be well received in inter-ethnic relations in Madura.

Changing Names into Native Madurese Names. In addition to language acquisition and mastery, name adaptation as a local identity is also a strategy for negotiating ethnic Chinese identity in Madura. Names are often considered to represent a cultural identity of a group of people. Sociologically, the name is formed socio-culturally, not appearing by itself or suddenly evolve in a vacuum. Names in Javanese culture, for example, are different from names in Batak culture of Indonesia because their roots and cultural structures are also different. This present study found that the adaptation of local Madurese names as a personal identity was often made by the ethnic Chinese descendants in Madura. 
"My Chinese name is actually Tjie Seng Yoe. The prefix Tjie is my family's clan. But my name on my KTP (Kartu Tanda Penduduk or identity card) is Bahrul Akbar. People also call me Arul, Kak (brother) Arul. Not Koh (brother) Tjie" (Bahrul, male, 35 years old).

"Samsuni is actually my name in KTP (Kartu Tanda Penduduk or identity card). At my office, people call me Pak Sam. My Chinese name is Yang Xian Ming. My family called me Aming. But many people here call me Sam Aming, it takes actually two names, from Samsuni and Yang Xian Ming, so become Sam Aming" (Samsuni, male, 54 years old).

As stated by Bahrul and Samsuni above, the strategy of using Madurese names as identity among ethnic Chinese in Madura takes place both formally and informally. Formally, the adaptation of Madurese names is made by registering or changing the name legally at Kantor Kependudukan dan Catatan Sipil (Population and Civil Registration Agency). Although currently there is no longer a prohibition on using Chinese names in Indonesia, some informants in this study deliberately did not use Chinese names, and instead, used native Madurese names (Aguilar 2001). Some informants in this study, for example, even used names that originally rooted in Arabic, like many Madurese names, even though they actually were not followers of Islam. Meanwhile, informally, the use of Madurese names occurs in the form of greetings in daily interactions. In Madura, it is common to call others with their nicknames based on the last syllable of the first name, for example, "Mad Hasan" for the name of Muhammad Hasan.

This study also found that the use of Madurese names was mostly made by individuals of older ethnic Chinese. By using the local name of the ethnic Madura, individuals of ethnic Chinese in this study stated that they tended to be more readily accepted in everyday life. Many informants shared their experience that only by knowing their Madurese-like names they would be considered as part of the "tretan dibhik" (fellow of the Madurese community). Such tactics for negotiating minority identities through name changing also occur in the neighboring country of Malaysia. In his research on the Chinese-Muslim minority group in Malaysia, (Hew $2010 \mathrm{~b}$ ) found that the use of the Malay names or Malay-Muslim names was deliberately carried out by ethnic Chinese-Muslims in Malaysia to facilitate the process of cultural assimilation.

Interestingly, this study also found that there were some ethnic Chinese individuals in Madura who had several different names. For example, when these Chinese individuals were in a circle of fellow ethnic Chinese, they would introduce 
themselves with their Chinese name. However, when they were in the Madurese ethnic environment, they would use their Madurese names. The practices of using different names were in accordance with Brekhus' concept of 'identity commuters' (2008). An identity commuter is an individual who moves from one identity domain to another according to the context of space and time. A commuter does not have a single master status of identity. The identity commuter who travels to identityspecific spaces to immerse him or her in an identity subculture is also committed to taking on an identity in its 'pure' and thus 'most authentic' form. He/she quickly moves to two or more loci of identity (such as names), as do the ethnic Chinese individuals who use different names in Madura.

Practicing the Madurese Cultural Traditions in Daily Life. Another strategy of identity negotiation of ethnic Chinese that is also commonly found in this study is the practice of Madurese's local cultural traditions. These local cultural traditions, for example, are traditional clothing, customs, and ceremonies. This study found that some ethnic Chinese in Madura carried out an adaptation process by using local cultural traditions, especially in terms of how to dress and how to conduct traditional ceremonies.

Most of the informants in this study stated that they were accustomed to use traditional Madurese clothing, for example, Marlena clothing for women and Sakera clothing for men. Also, the strong influence of Islam in Madura has influenced the way of ethnic Chinese dressing in their daily activities. Some male informants in this study, for example, stated that they were accustomed to wearing sarong (a traditional fabric commonly wear by Muslim men in Madura) in their daily activities like most Madurese male, despite they are not Muslims.

"I often wear Muslim clothing on many occasions today. I went to school and university wearing hijab. When I have to come to social event in my kampong (village), like Molodhen (Prophet's Mohammad Birthday celebration) at mosque, I was always wearing hijab" (Hanna, female, 36 years old).

"I continue to follow and adapt like the Madurese men, I also wearing a sarong and a kopiah (black skullcap) if there is a social event. I respect my community, even though I have a different religion. I am Christian. But, I don't want to be too different from my friends and neighbors" (Bakir, male, 40 years old). 
As stated by Hanna, this study also found that there were female ethnic Chinese informants in Madura who were not reluctant to wear a hijab (headscarves for Muslim women) when they had to participate in social activities with other Madurese women in their community. They use the hijab with a reason to respect the local tradition of the majority of native Madurese, even though actually they are not Muslim (they are Christians). According to these informants, they use the hijab at certain times, for example, when attending a social gathering or invitation, and do not use the hijab at all times.

In addition to the adaptation of cultural traditions in the form of Madurese ways of clothing, such as hijab and sarong, another attribute that is widely used as a strategy for identity negotiation of ethnic Chinese in Madura is the holding of traditional Madurese ceremonies, such as in celebrating childbirth and marriage (Aguilar 2001). Although not all, some informants of ethnic Chinese-Muslim in this study stated that they followed the local Madurese rites to celebrate the birth of children and marriages that were close to Islam. In this sense, the ethnic Chinese in Madura have tried to become an 'identity integrator' (Brekhus 2015) who unites various elements of their different identities within themselves. Furthermore, by trying to adopt the native Madurese cultural traditions, they wanted to be worthy of being called 'oreng Madhure' (Madurese people), rather than 'orang Tionghoa' (Chinese descendents) in Madura.

Embracing Islam as Their New Religion. Most of the ethnic Chinese in Madura are Christians, Catholics or Confucians. The history of their migration from other regions to Madura was driven more by economic factors, not for religious reasons. However, some ethnic Chinese in Madura are Muslims. In some areas in the eastern region of Madura, for example in Sumenep Regency, there are even Chinese-Muslim villages that have existed for a long time and have survived to the present time.

"My wife is a Muslim, and my wife is from Sumenep. In her village in Sumenep, all people are Muslims. Yes, I think if we enter a region, we have to follow and adjust to the majority. Because I married my wife, who is a Muslim, so I became a Muslim" (Supriadi, male, 45 years old).

The strategy of identity negotiation of ethnic Chinese in Madura through religion did not to occur very often. Changing religious identities, compared to other identities, is often not easy to do. Adhering or converting to specific religions, 
including Islam, cannot be done immediately for the sake of social adaptation alone. The process of converting to Islam among ethnic Chinese in Madura occurred because it was influenced by many factors. The closeness and interest in Islamic teachings practiced by the majority of native Madurese are one of them. Some Chinese-Muslim informants in this study stated that they became Muslims not because of coercion, but because of their own initiative. Some other informants also stated that they had become Muslims since birth because their parents were also Muslims.

Historically, ethnic Chinese in Madura have converted to Islam since the 17th century (Erawati 2012; Farid 2019). This conversion is mostly voluntary and is driven by specific factors of close interaction and culture between ethnic Chinese and Madurese. In Dungkek Village in Sumenep Regency, for example, even there is a location of a traditional Chinese-Muslim community (Erawati 2012). Based on the story from the informants in this study, Dungkek Village was originally a stopover for workers from China and the location of natural materials used to build the Sumenep Mosque. From there then, the process of interactions occurred until many ethnic Chinese embraced Islam in Madura (Erawati 2012).

The choice to become Chinese-Muslims in the predominantly Muslim Madurese was acknowledged by some informants in this study to provide many benefits. The Madurese people character as religious, pious, adhering to the principle of client-patron, and observing religious teachings through religious figures of "kyai" or clerics, makes Madurese people more readily accept those of the same religion (Pribadi 2018). By embracing Islam, the ethnic Chinese minority in Madura seemed to have been considered as 'legitimate' to become a fully native Madurese. From the perspective of Brekhusian's identity typology (2008), the ethnic Chinese in Madura who embraced Islam are trying to build a marked identity capital as 'identity integrators' so that it is more readily accepted in everyday social relations. In addition, the primordial ties of Madurese who were strongly influenced by traditional Islamic teachings and became the main followers of the Nahdlatul Ulama (the biggest Muslim organization in Indonesia), were also felt to bring an important social capital for ethnic Chinese-Muslims in Madura (Bourdieu 1986; Hidayat 2017). By having an identity as a Muslim, Chinese-Muslim individual in 
Madura is readily accepted as part of the social network of the majority Muslim's Madurese community.

Marrying Native Madurese Men or Women. The strategy of identity negotiation of ethnic Chinese in inter-ethnic relations in Madura was also carried out by marrying Madurese men or women. The choice of this strategy, although not many, was conveyed by some informants who had parents of different ethnic backgrounds.

"My mother is a native Madurese, and Muslim. My father is Tionghoa (Chinese-Indonesian). My grandpa said that before my mother married my father, there was a kind of contract given to my father, who was nonMuslim. My grandpa said to my father, "If you want to get married, you must convert into Islam." My mother and father were falling in love, and they intend to have a more serious relationship. And then my father said yes, he converted into Islam" (Dzaky, male, 24 years old).

Inter-ethnic marriages, and often also inter-religion marriages, between ethnic Chinese and Madurese have been going on for a long period of time. In the Chinese-Muslim villages in Sumenep Regency, for example, there has been a longstanding marriage of ethnic differences between ethnic Chinese and native Madurese. Some factors lie behind the occurrence of marriages of different ethnicities, such as shared views of live, shared interests, similarity in work, to similarity in religion. Most of the informants in this study stated that marriages between ethnic Chinese and Madurese were carried out on the basis of love and without coercion. However, there are also marriages that are motivated by factors of debt or the coercion of the surrounding environment.

This strategy of identity negotiation of ethnic Chinese through marriages was practiced by both Chinese men and women. Some informants in this study stated that the marriage between Chinese men and Madurese women usually brought a more dominant influence on the Chinese side. These include the conversion of the women to follow the religion of the men. On the other hand, the marriage between Madurese men and Chinese women will bring a more dominant influence on Madurese side, including the conversion of the women to become a Muslim woman before marriage.

Among Indonesians, there were official categories of pribumi (native) and non-pribumi (non-native) - mostly based on race - with the former being regarded as the 'authentic' inhabitants of the land (Hoon 2006). Although it is not easy and 
often differs in many ways - physical, ethnic, cultural, economic, social, religious - but when it has decided to get married, then the couple who are full of differences will be considered as 'oreng Madhure' (native Madurese) (De Jonge 1989; Tan 2008). The label of 'oreng Madhure', as an identity capital obtained by ethnic Chinese who married a native Madurese, will last as long as the marriage relationship remains. Identity negotiation strategies by marrying Madurese men or women carried out by several ethnic Chinese informants in this study were also found in some previous studies (Erawati 2012; Farid 2019; De Jonge 1989, 2012; Oetomo 1998; Rifai 2007).

The findings of this study shows that individuals of ethnic Chinese in Madura - who have a variety of identity intersections - practice identity negotiations in their daily lives. They attempt to bracket their multiple identity affiliations, shifting from one identity to another identity and living double or even multiple lives, and many others bring their many identity affiliations together to form one multiply influenced and socially networked self (Brekhus 2008). These practices of identity negotiations are carried out to facilitate the process of acculturation of ethnic Chinese in Madura. Acculturation occurs when an individual begins to adopt a cultural identity other than his cultural identity (Tan, Ngah, and Darit 2017). This is different from the assimilation that occurs when an individual must unite or become part of a dominant culture and give up his/her own cultural identity.

Under the Indonesia's Soeharto New Order regime, the political practices of Pembauran or assimilation with coercion which discriminated against ethnic Chinese took place. Referring to this policy, for example, ethnic Chinese in Indonesia are prohibited from using Chinese cultural attributes, traditions, names, and languages in daily life (Chong 2015; Freedman 2003; Hoon 2006; Purdey 2003; Suryadinata 2001). The assimilation with coercion of ethnic Chinese in the Indonesia's New Order regime was originally intended to include ethnic Chinese as an integral part of the Indonesian culture. They were asked to give up their ethnic Chinese identity and become 'Indonesian.' However, the tragedy of the 1998 antiChina riots proved that the policy of coercion assimilation did not achieve what the New Order regime wanted. According to (Purdey 2003) noted, these riots had twin effects: they generated a renewed awareness among these minorities of their 
ethnicity and particularly of their vulnerability in Indonesia, as well as a widely felt realization that the assimilation project had indeed failed.

Ethnic Chinese in Indonesia are often regarded as 'Asing' (foreigners), 'Aseng' or non-pribumi (non-native), and therefore subject to various forms of discriminatory treatment (Astutik and Effendi 2016; Hoon 2006; Suryadinata 2002; Suryana 2018). A national survey in 2016 by ISEAS-Yusof Ishak Institute, Singapore, found that the majority of pribumi (native Indonesian) respondents agreed to statements about Chinese Indonesians' alleged economic dominance and privilege, with almost $60 \%$ saying that ethnic Chinese are more likely than indigenous Indonesians to be wealthy (Hew 2010a). The survey also confirmed the existence of negative prejudices against ethnic Chinese influence in Indonesian politics and economy, and many natives believe that Chinese Indonesians may harbor divided national loyalties (Setijadi 2017). In various cases, the failure of the assimilating cultural identity in Indonesia is often seen as one of the causes of interethnic conflicts in Indonesia (Davidson 2003; Dawis 2010; Hoon 2006). It was this policy of coercion assimilation that failed in the New Order era that made ethnic Chinese in Indonesia has to compromise with reality as a minority that often experienced discrimination (Muzakki 2010).

In contrast to the Indonesia's New Order era which applied the practice of forced assimilation, ethnic Chinese in Madura today are more inclined to carry out acculturation processes (Freedman 2003; Hoon 2006). The practices of identity negotiation of ethnic Chinese in Madura are one of these acculturation strategies. The practices of identity negotiation take place through various forms: selfappearance, self-identification, behaviors, and interaction with others (Swann 2005; Swann and Bosson 2008). Individuals in minority groups with different identities ethnicity, race, gender, religion, social status - often have to do identity negotiation practices in order to be accepted and live in harmony within their social environment (Tan et al. 2017). The strategic choices of identity negotiations are heavily influenced by various external conditions such as social, cultural, historical, and geopolitical backgrounds, occupations, neighborhoods, and group affiliations, as well as race, gender, sexuality, and class backgrounds (Hidayat 2016).

Some researchers note that the ethnic Chinese groups in Madura are known as one of the non-Madurese ethnic groups who can understood, appreciated, and accepted the existence of 'local genius' or local knowledge of the native Madurese 
people (De Jonge 1989, 2012; Kuntowijoyo 2017). The ethnic Chinese in Madura are seen as capable of conducting identity negotiation practices in their social interactions quite smoothly, for example by wanting to be involved in the practices of local Madurese cultural traditions, respecting Madurese cultural philosophy namely 'bhuppa, bhâbbhu, ghuru, rato' (Father, Mother, Teacher, Government), willing to claim as 'oreng Madhure' (native Madurese), and even to use Basa Madhura (Madurese language) in their daily conversation (Hew 2018; De Jonge 1989, 2012; Rifai 2007). The long history of the ethnic Chinese coming into Madura since 1790 (Davidson 2003; Setiono 2008) as well as the meeting of Chinese cultural values and Madurese values, seems to significantly contribute to the development of tolerance and harmony in Madura today.

Various forms of identity negotiation practice carried out by ethnic Chinese in Madura today are thus marked by the absence of external coercion and the emergence of internal awareness to 'adapt' to the new environment (Farid 2019; Hew 2018; Swann and Bosson 2008; Swann et al. 2009; Ting-Toomey 2015). The findings of this study clearly show some strategies taken by ethnic Chinese to be accepted harmoniously in the structure of the majority ethnic Madurese and the Muslim community. Unconditional willingness of ethnic Chinese to use Madurese language, rather than Mandarin, in everyday conversation, or their choice to use Madurese names and cultural attributes, or their decision to convert to Islam, rather than Christianity, Catholicism or Confucianism, or their courage to marry Madurese men or women of different ethnic origin (Parker, Hoon, and Raihani 2014; Tan et al. 2017), corroborated the process of voluntary identity negotiation practice as presented by others (Swann and Bosson 2008; Ting-Toomey 2015). As their ultimate goal is to create a peaceful and harmonious life in their homeland of Madura, the ethnic Chinese in Madura are willing to voluntarily adapt and negotiate various dimensions of identities that they have in daily life situations.

\section{CONCLUSION}

In general, this study found that the practices of identity negotiation of ethnic Chinese in two regencies in Madura - Bangkalan Regency and Sumenep Regency - was carried out in various ways which included the using of local 
language in daily conversation, changing their Chinese names into native Madurese names, practicing the Madurese indigenous cultural traditions in daily life, embracing Islam - the majority religion of the native Madurese - as their new religion, and marrying native Madurese men or women. In particular, by taking into account the differences in location and the socio-cultural characteristics, this study found that the identity negotiation process for ethnic Chinese in Sumenep Regency has occurred in a relatively longer time than in Bangkalan Regency. This was mainly caused by the historical background of Chinese immigration to Madura Island, who entered through Sumenep Regency and not Bangkalan Regency. However, this study also found that the identity negotiation process of ethnic Chinese in Bangkalan Regency has taken place in a relatively easier way than in Sumenep Regency. One of the factors that caused this easiness was the more egalitarian and open characters of the people of Bangkalan Regency, as compared to the more feudal, exclusive and closed characters of the Sumenep Regency's people since it was a former kingdom in the past. The findings of this study corroborated other prior studies that in unequal inter-ethnic relations, the ethnic minority often have to sacrifice themselves to be accepted by the ethnic majority. This is obvious with the willingness of the ethnic Chinese in Madura to adapt and acculturate, accept the cultural elements of the Madurese people, and at the same time, eliminate the elements of their own native culture. Moreover, the ethnic Chinese minorities in Madura often have to negotiate their identities, by hiding their master identity (especially their racial and religious identity) and highlighting other minor identities (such as their social class, gender, citizenship, geographical position, occupation, tastes, hobbies, life experiences, friendship networks, or family relationships), in order to be accepted and coexist with the ethnic Madurese majority. However, and it is important to underline here, the process of acculturation carried out by the ethnic Chinese in Madura did not occur under pressure or coercion. On the contrary, the process of acculturation of the ethnic Chinese in Madura was carried out relatively voluntarily, peacefully and harmoniously. The results of this study underline the importance of a more comprehensive understanding of the practices of identity negotiation in the relations of minority-majority ethnic groups in Indonesia. The process of adaptation, acculturation or assimilation among different ethnic groups in Indonesia thus should take close attention to the dynamic of identity negotiations of each ethnic 
involved. The making of policies or regulations to prevent ethnic conflicts should, therefore, consider the consequences of the practices of identity negotiations among ethnic minorities in inter-ethnic relations in Indonesia. Finally, the efforts to develop a body of knowledge for identity negotiation practices among ethnic minority groups in Indonesia should receive more attention given the fact that ethnic diversity in Indonesia is vulnerable to triggering horizontal conflicts which are often based on ethnic identities.

\section{ACKNOWLEDGEMENT}

This research was supported by a grant from the LPPM Universitas Trunojoyo Madura. The authors would like to thank LPPM Universitas Trunojoyo Madura for this research grant opportunity.

\section{REFERENCES}

Aguilar, Filomeno. 2001. "Citizenship, Inheritance, and the Indigenizing of 'Orang Chinese’ in Indonesia.” Positions: East Asia Cultures Critique 9(3):501-33.

Arifin, Evi Nurvidya, Sairi Hasbullah, and Agus Pramono. 2016. "Chinese Indonesians: How Many, Who and Where?” Asian Ethnicity 18(2):310-29.

Astutik, Juli, and Tonny Dian Effendi. 2016. "Holistic Participative Based Model on Ethnic Mix Relations for Conflict Resolution: Case Study on Tionghoa (Chinese Indonesian) and Javanese Relations in Malang City, Indonesia." International Journal of Asian History, Culture and Tradition 3(2):1-13.

Bourdieu, Pierre. 1986. "The Forms of Capital." in Handbook of Theory and Research for the Sociology of Education. New York: Greenwood Press.

Brekhus, Wayne. 1996. "Social Marking and the Mental Coloring of Identity: Sexual Identity Construction and Maintenance in the United States." Sociological Forum 11(3):497-522.

Brekhus, Wayne. 2008. "Trends in the Qualitative Study of Social Identities." Sociological Compass 2(3):1059-78.

Brekhus, Wayne. 2015. Culture and Cognition: Patterns in the Social Construction of Reality. Cambridge: Polity Press.

Brekhus, Wayne, David L. Brunsma, Todd Platts, and Priya Dua. 2010. "On the 
Contributions of Cognitive Sociology to the Sociological Study of Race." Sociological Compass 4(1):61-76.

Chong, Wu-Ling. 2015. "Local Politics and Chinese Indonesian Business in PostSoeharto Era." Southeast Asian Studies 4(3):487-532.

Cohen, Julie, and Anusha Kassan. 2018. "Being In-between: A Model of Cultural Identity Negotiation for Emerging Adult Immigrants." Journal of Counseling Psychology 65(2):133-54.

Creswell, John. 2013. Qualitative Inquiry and Research Design. California: Sage Publications.

Davidson, Jamie. 2003. "The Politics of Violence on an Indonesian Periphery." South East Asia Research 11(1):59-89.

Dawis, Aimee. 2010. The Chinese of Indonesia and Their Search for Identity: The Relationship between Collective Memory and the Media. New York: Cambria Press.

De Jonge, Huub. 1989. Agama, Kebudayaan, Dan Ekonomi: Studi-Studi Interdisipliner Tentang Masyarakat Madura. Jakarta: Rajawali Press.

De Jonge, Huub. 2012. Garam Kekerasan Dan Aduan Sapi: Esai-Esai Tentang Orang Madura Dan Kebudayaan Madura. Yogyakarta: LKIS.

Erawati, Yunita. 2012. "Komunitas Cina Muslim Desa Dungkek, Kabupaten Sumenep (1966-1998).” Universitas Negeri Malang.

Farid, Zainul. 2019. "Sejarah Perkembangan Masyarakat Muslim Tionghoa Di Dungkek Kabupaten Sumenep Abad Ke-XVIII.” Universitas Islam Negeri Sunan Ampel Surabaya.

Freedman, Amy. 2003. "Political Institutions and Ethnic Chinese Identity in Indonesia." Asian Ethnicity 4(3):439-52.

Goffman, Erving. 1959. The Presentation of Self in Everyday Life. New York: Doubleday.

Heidhues, Mary. 1996. "Identity and the Minority: Ethnic Chinese on the Indonesian Periphery." Indonesia Circle. School of Oriental \& African Studies. Newsletter 24(70):181-92.

Heryanto, Ariel. 1998. "Ethnic Identities and Erasure: Chinese Indonesians in Public Culture." in Southeast Asian Identities. London: Institute of Southeast Asian Studies. 
Hew, Wai. 2010a. "Chinese Muslim Cultural Identities: Possibilities and Limitations of Cosmopolitan Islam in Indonesia." in Religious Diversity in Muslim-Majority States in Southeast Asia: Areas of Tolerance and Conflict. Singapore: ISEAS-Yusof Ishak Institute.

Hew, Wai. 2010b. "Naming and Chinese Muslims Identities: Boundary-Making, Negotiation and Hybridity in Malaysia." in Personal Names in Asia: History, Culture and Identity. Singapore: NUS Press.

Hew, Wai. 2018. Chinese Ways of Being Muslim: Negotiating Ethnicity and Religiosity in Indonesia. Copenhagen: Nias Press.

Hidayat, Medhy. 2016. "Liminal Lives: Presentation of Self Among Muslim Immigrants in a Small Midwestern City." University of Missouri. USA.

Hidayat, Medhy. 2017. "Ibadat, the Body and Identity: Islamic Rituals and the Construction of Muslim Identity." The Journal of Society \& Media 1(2):117.

Hoon, Chang-Yau. 2006. "Assimilation, Multiculturalism, Hybridity: The Dilemmas of the Ethnic Chinese in Post-Soeharto Indonesia." Asian Ethnicity 7(2):149-66.

Kuntowijoyo. 2017. Perubahan Sosial Dalam Masyarakat Agraris Madura 18501940. Yogyakarta: Diva Press.

Muzakki, Akh. 2010. "Ethnic Chinese Muslims in Indonesia: An Unfinished AntiDiscrimination Project.” Journal of Muslim Minority Affairs 30(1):81-96.

Oetomo, Dede. 1998. "Multilingualism and Chinese Identities in Indonesia." in Changing Identities of the Southeast Asian Chinese Since World War II. Hong Kong: Hong Kong University Press.

Parker, Lyn, Chang-Yau Hoon, and Raihani. 2014. "Young People's Attitudes towards Inter-Ethnic and Inter-Religious Socializing, Courtship and Marriage in Indonesia." South East Asia Research 22(4):467-86.

Pribadi, Yanwar. 2018. "The Klebun, the Kiai and the Blater: Notes from Western Madura, Indonesia." South East Asia Research 23(3):303-17.

Purdey, Jemma. 2003. "Political Change Reopening the Asimilasi vs Integrasi Debate: Ethnic Chinese Identity in Post-Soeharto Indonesia." Asian Ethnicity 4(3):421-37.

Rifai, Mien. 2007. Manusia Madura: Pembawaan, Perilaku, Etos Kerja, Penampilan, Dan Pandangan Hidupnya Seperti Dicitrakan Peribahasanya. Yogyakarta: Pilar Media. 
Sai, Siew-Min, and Chang-Yau Hoon. 2012. Chinese Indonesians Reassessed: History, Religion and Belonging. London: Routledge.

Scott, Susie. 2016. Negotiating Identity: Symbolic Interactionist Approaches to Social Identity. New York: John Wiley \& Sons.

Setijadi, Charlotte. 2017. Chinese Indonesians in the Eyes of the Pribumi Public. Singapore: Yusof Ishak Institute.

Setiono, Benny. 2008. Tionghoa Dalam Pusaran Politik: Mengungkap Fakta Sejarah Tersembunyi Orang Tionghoa Di Indonesia. Jakarta: Transmedia.

Suryadinata, Leo. 2001. "Chinese Politics in Post-Soeharto Indonesia: Beyond the Ethnic Approach?” Asian Survey 41(3):502-24.

Suryadinata, Leo. 2002. Negara Dan Etnis Tionghoa: Kasus Indonesia. Jakarta: LP3ES.

Suryana, Aan. 2018. "Indonesian Presidents and Communal Violence against NonMainstream Faiths.” South East Asia Research 26(2):147-60.

Swann, William. 1987. "Identity Negotiation: Where Two Roads Meet." Journal of Personality and Social Psychology 53(1):1038-51.

Swann, William. 2005. "The Self and Identity Negotiation.” Interaction Studies 6(1):69-83.

Swann, William, and Jennifer Bosson. 2008. "Identity Negotiation: A Theory of Self and Social Interaction. Handbook of Personality: Theory and Research." in Handbook of Personality: Theory and Research. New York: The Guilford Press.

Swann, William, Russell Johnson, and Jennifer Bosson. 2009. "Identity Negotiation at Work." Research in Organizational Behavior 29(1):81-109.

Tan, Mely. 1987. "The Role of Ethnic Chinese Minority in Development: The Indonesian Case.” Southeast Asian Studies 25(3):363-82.

Tan, Mely. 2008. Etnis Tionghoa Di Indonesia: Kumpulan Tulisan. Jakarta: Yayasan Obor Indonesia.

Tan, Yao, Kamarudin Ngah, and Sezali Md Darit. 2017. "Formation and Negotiation of Identity: The Case of the Kelantan Kampung Pasir Parit Peranakan Chinese." Asian Ethnicity 19(1):16-35.

Ting-Toomey, Stella. 2015. "Identity Negotiation Theory." in The SAGE Encyclopedia of Intercultural Competence. London: Sage.

Turner, Sarah, and Pamela Allen. 2007. "Chinese Indonesians in a Rapidly 
Hidayat: Strangers at Home: Identity

Negotiation Practices among Ethnic

Chinese in Madura, Indonesia

Changing Nation: Pressures of Ethnicity and Identity." Asia Pacific Viewpoint 48(1):112-27. 